\title{
HLA-DPB1 wt Allele
}

National Cancer Institute

\section{Source}

National Cancer Institute. HLA-DPB1 wt Allele. NCI Thesaurus. Code C52342.

Human HLA-DPB1 wild-type allele is located in the vicinity of 6p21.3 and is approximately $24 \mathrm{~kb}$ in length. This allele, which encodes HLA class II histocompatibility antigen, DP(W4) beta chain protein, is involved in the modulation of antigen presentation. 